\title{
Research Article \\ Effect of Parboiling Conditions on Physical and Cooking Quality of Selected Rice Varieties
}

\author{
Ayenew Meresa $(\mathbb{D}$, Ayalew Demissew $(\mathbb{D}$, Seifu Yilma, Getu Tegegne, and Kiber Temesgen \\ Amhara Agricultural Research Institute (ARARI), P.O. Box 527, Bahir Dar, Ethiopia \\ Correspondence should be addressed to Ayenew Meresa; ayenew.meresa@arari.gov.et
}

Received 12 June 2020; Revised 18 August 2020; Accepted 2 September 2020; Published 9 September 2020

Academic Editor: Jaime Yanez

Copyright ( 2020 Ayenew Meresa et al. This is an open access article distributed under the Creative Commons Attribution License, which permits unrestricted use, distribution, and reproduction in any medium, provided the original work is properly cited.

\begin{abstract}
Most locally cultivated rice varieties in Ethiopia have low physical (low head rice yield, high broken rice yield, and high percentage of chalkiness) and cooking qualities (low water uptake ratio and swelling ratio). Parboiling, a process which involves soaking, steaming, and drying, has been identified as a key technique to improve cooking and milling quality of rice. The current study is aimed at elucidating the effect of parboiling on physical and cooking qualities of three rice varieties (Gumara, Edget, and Narica4) collected from Fogera National Rice Research and Training Center, Amhara region, Ethiopia. Each rice variety was subjected to different soaking temperatures $\left(40^{\circ} \mathrm{C}, 50^{\circ} \mathrm{C}, 60^{\circ} \mathrm{C}, 70^{\circ} \mathrm{C}\right.$, and $\left.80^{\circ} \mathrm{C}\right)$ and steaming time $(10,20,30,40$, and 50 minutes). The treatment effect results indicated that parboiling has a significant effect $(P<0.05)$ on head rice yield and percentage of broken rice with increased soaking temperature and steaming time as compared to the control. For instance, percent head rice yield increased as soaking temperature (from 40 to $80^{\circ} \mathrm{C}$ ) and steaming time (from 10 to 50 min) increased: for Gumara, from 4.07 to $93.6 \%$, for Edget, 9.47 to 96.53 , and from 3.20 to 91.67 for Narica4. Percentage chalkiness had decreased as soaking temperature and steaming time increased: $97.33 \%$ to $0.00 \%$ for Gumara, $97.80 \%$ to $0.00 \%$ for Edget, and $100.00 \%$ to $0.13 \%$ for Narica 4 as compared to $100 \%$ for control of all varieties. The minimum cooking time was identified as $16-$ $23 \mathrm{~min}$ for Gumara, 16-23 min for Edget, and 15-20 min for Narica4 rice varieties. The result of the present study clearly showed that parboiling with high soaking temperature and steaming time increased the head rice yield, water uptake ratio, decreased percentage chalkiness, and enhanced the overall quality of the rice varieties.
\end{abstract}

\section{Introduction}

Rice (Oryza sativa L.) is a sole cereal crop cooked and consumed mainly as whole grain and hence considerations on grain quality are much more relevant than other food crops [1]. Rice supplies high-value carbohydrates accounting for more than $50 \%$ of the daily calorie intake, and it is consumed by more than $67 \%$ of the world's population $[2,3]$.

According to the Central Statistical Agency [4] of Ethiopia report, the number of farmers engaged in rice production was about 115 thousand in 2012/13, and it has increased to about 161 thousand in 2017/18 [5]. Similarly, the area covered showed an increment from about 41 thousand ha in 2012/13 [4] to about 53 thousand ha in 2017/18 [5] along with increased production from about 121 thousand tons in $2012 / 13$ [4] to 151 thousand tons in 2017/18 [5]. Although the production shows an increment through time, there is a substantial postharvest loss during rice milling. Furthermore, the local rice has low market price due to its poor cooking quality due to high breakage during milling, chalky grains, low head rice, and low water absorption capacity.

Parboiling is a hydrothermal process consisting of soaking, heating, and drying operations modifying the qualitative and processing behavior of rice $[6,7]$. Soaking is a hydration process in which the diffusion-controlled water uptake migrates into the rice kernel [8], and continuous heating leads to nonreversible swelling and fusion of starch granules. Due to the reason that starch granules are gelatinized, followed by relevant reassociation, different changes occur in rice that plays an important role in various postharvest handling and processing operations, such as storage, milling, cooking, and eating qualities [9]. Due to the diversity in 
genetic and environmental factors [10, 11], different rice varieties vary in their cooking and sensory characteristics [12].

Locally milled rice in Ethiopia is poor in quality, usually consumed in rural areas, and cannot compete with imported rice both in terms of price and quality. The poor cooking quality of the local rice makes urban consumers to prefer imported rice to local ones. Hence, there is a need to improve the quality of locally produced rice in terms of physical and cooking attributes of the grain in order to make it competitive with imported ones.

\section{Materials and Methods}

2.1. Sampling. About 50 kilograms of paddy rice of each selected rice variety (Narica-4, Edget, and Gumara) harvested in 2017 and stored for six months was collected from Fogera National Rice Research and Training Center, where the milling activity was also performed. Experiments on parboiling processes, physical quality analysis, and the cooking quality analysis were conducted at the Food Science and PostHarvest Handling Research Directorate laboratory, Amhara Agricultural Research Institute, Bahir Dar, Ethiopia.

2.2. Experimental Design. The experiment consisted of two treatments with five levels and one control. Soaking temperature $\left({ }^{\circ} \mathrm{C}\right)$ and steaming time (minutes) were the treatments of the experiment. Five temperatures $(40,50,60,70$, and $80^{\circ} \mathrm{C}$ ) at a constant soaking time and five steaming durations $(10,20,30,40$, and $50 \mathrm{~min})$ were the levels of the treatments. A complete randomized design was employed for the levels and each was replicated three times.

2.3. Parboiling Process. The laboratory parboiling procedure was conducted according to the method described by Danbaba et al. [13] with some modification. A laboratory water bath (Clifton unstirred bath, England) with temperature regulation of $\pm 2^{\circ} \mathrm{C}$ was used for soaking rice grains before steaming to produce parboiled rice. About $14 \mathrm{~kg}$ of rice sample was put in a perforated dish and soaked in a water bath. Soaking was done in hot water of five different temperatures $(40,50$, 60,70 , and $80^{\circ} \mathrm{C}$ ) at constant soaking time. Then the soaked sample was steamed for five steaming durations (10, 20, 30, 40 , and $50 \mathrm{~min}$ ) over boiling water. After steaming, the parboiled paddy was spread on a tray with a thickness of about $2 \mathrm{~cm}$ at ambient condition for about 4 days to dry until equilibrated to $12-14 \%$ moisture content. The dried parboiled rice sample was dehusked (TYPE $25 \mathrm{M}$, Oya Tanzo Manufacturing Co., Ltd, Japan), polished (CBS550BS, SATAKE, Japan), and packed with plastic bags till analysis.

\subsection{Determination of Physical Characteristics}

2.4.1. Moisture Content. Grain moisture content was measured in triplicates using a digital moisture meter (Riceter J301, KETT, Japan).

2.4.2. Husking/Milling Quality. From $1.2 \mathrm{~kg}$ of paddy rice, it was done by the removal or separation of husk and bran to recover the edible portion of rice. The milling quality (husk- ing efficiency or recovery percentage) was calculated according to the international rice research institute method [14] as follows:

Milling quality $(\%)=\frac{\text { Mass of milled rice }(\text { grams })}{\text { Mass of original paddy sample }(\text { grams })} * 100$.

2.4.3. Percentage of Broken Rice. Broken rice is an estimate of those kernels that are less than $3 / 4$ of their normal length after milling (dehusking). This was determined by weighing $50 \mathrm{~g}$ samples of polished rice and separating into broken and unbroken fractions. This was done manually with careful handpicking and repicking. Each portion was weighed and expressed as a percentage of the initial weight of rice. This was conducted by the method followed by Adu-Kwarten et al. [15].

$$
\text { Broken rice }(\%)=\frac{\text { Weight of broken grains }}{\text { Weight of taken sample }} * 100 \text {. }
$$

2.4.4. Percentage of Head Rice. From a $50 \mathrm{~g}$ sample of cleaned and milled rice, the head rice was manually separated and weighed. Milled rice grains with a length greater than three quarters of complete grains were classified as head rice. The head rice yield was calculated using the method followed by Fofana et al. [16] with some modifications by calculating head rice percentage instead of head rice ratio.

$$
\text { Head rice yield }(\%)=\frac{\text { Weight of head rice }}{\text { Weight of milled rice sample }} * 100 \text {. }
$$

2.4.5. Percentage Chalkiness. Percentage of rice chalkiness was calculated from three replicates of $50 \mathrm{~g}$ samples, according to the method outlined by WARDA [17]. The amount of chalk in the milled rice was measured using seed viewer florescent (QUG/A2-SL, UK) for transmission of light. A perfect rice grain is translucent, allowing the transmission of light, whereas opaque or chalky areas in a chalky grain prevent this transmission. Chalkiness is expressed as the proportion of opaque relative to translucent areas in rice grains.

$$
\text { Chalkiness }(\%)=\frac{\text { Weight of chalky grain }}{50 \mathrm{~g} \text { samples }} * 100 \text {. }
$$

\subsubsection{Determination of Cooking Properties}

(1) Minimum Cooking Time (MCT). This was done according to Singh et al. [11]. About $2 \mathrm{~g}$ head rice samples was taken in a test tube and cooked in $20 \mathrm{ml}$ distilled water in a boiling water bath. The cooking time was determined by removing a few kernels at different time intervals during cooking and pressing them between two glass plates until no white core was left

(2) Water Uptake Ratio. Water uptake ratio of cooked rice was determined by the increase in weight of rice after 


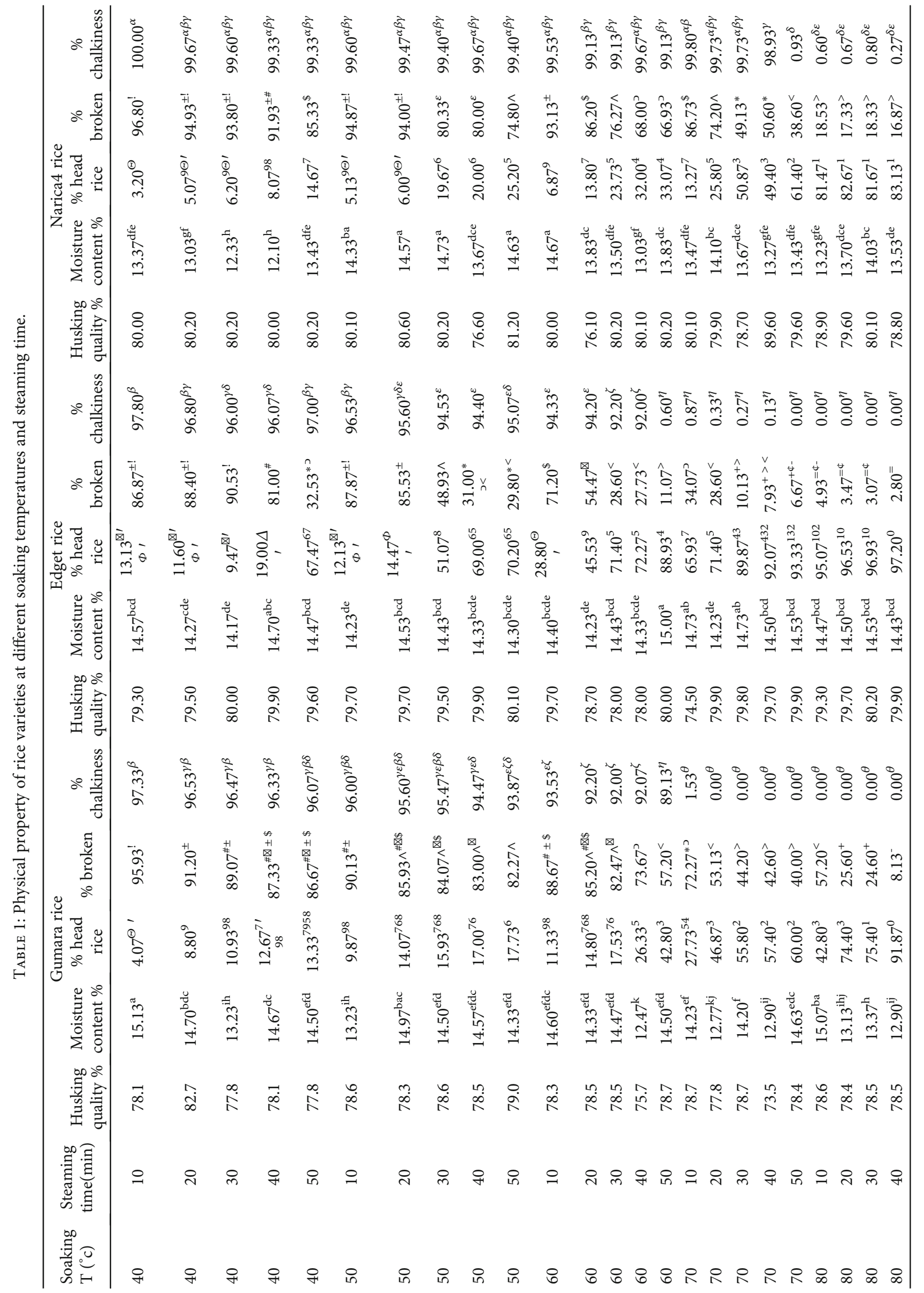




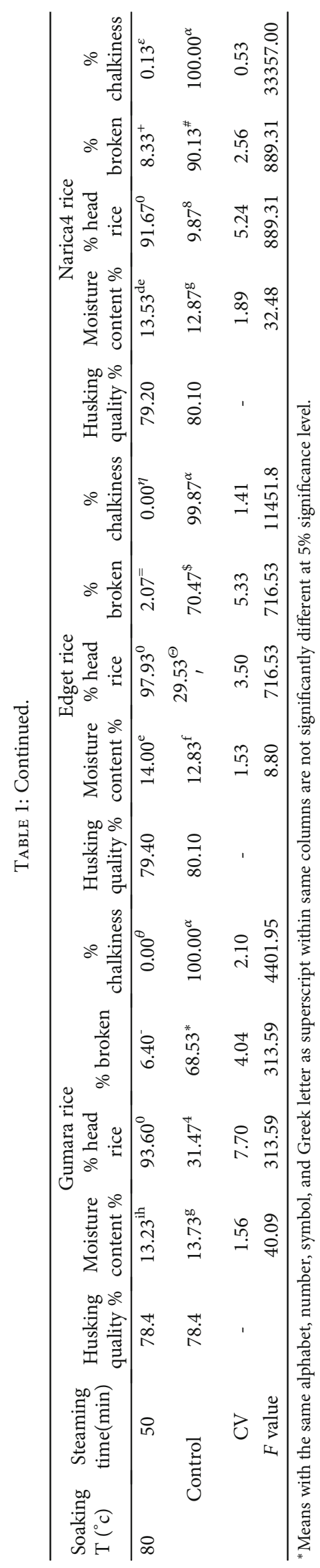


subjecting it to MCT as described above. Eight grams of rice was cooked with $100 \mathrm{ml}$ water in a $200 \mathrm{ml}$ cylinder on an electric heater [18]. Water uptake ratio was calculated as

$$
\text { Water uptake ratio }=\frac{\text { Weight of cooked rice }}{\text { Weight of raw rice }} \text {. }
$$

(3) Swelling Ratio. Milled rice (8g) was placed into a wire mesh cooking basket. The height of the raw rice in the cooking basket was measured using a digital caliper (SS17DV150, China) (H1). The samples were cooked according to the cooking times determined above. The cooking basket was subsequently removed and stood erect for 2 minutes for the water to drain off. The height of the cooked rice in the cooking basket was measured using a digital caliper (H2). This determination was carried out in triplicate [16]

$$
\text { Swelling ratio }=\frac{\text { Height of cooked rice }(\mathrm{H} 2)}{\text { Height of raw rice }(\mathrm{H} 1)} \text {. }
$$

2.4.7. Data Analysis. Data were analyzed using the SAS software version 9.0 and one-way analysis of variance (ANOVA) followed by Duncan's multiple range test for the multiple comparison analysis was carried out. Statistical significant test was carried out at 0.05 probability level.

\section{Result and Discussion}

3.1. Physical Characteristics of Rice Varieties. The mean moisture content for paddy Gumara rice ranged from $12.47 \%$ to $15.13 \%$, from $14 \%$ to $15 \%$ for Edget, and for Narica4, it ranged from $12.10 \%$ to $14.73 \%$ (Table 1 ). There was significant difference between the combination of each soaking temperature and steaming time treatments $(P<0.05)$ for the three varieties (Table 1). In general, the moisture contents of the tested rice varieties were comparable with those reported by Bleoussi et al. [19] (14\%), Farhan et al. [20] (10-12\%), Adu-Kwarten et al. [15] (14\%), Prasad et al. [21] (13-14\%), and Ayamdoo et al. [22] (15\%).

Table 1 shows that there was significant difference $(P<0.05)$ within each soaking temperature and steaming time treatment combination for the three rice varieties with respect to head rice yield. In general, the head rice yield of the three rice varieties had increased as the soaking temperature and steaming time increased. Gumara, Edget, and Narica 4 rice varieties soaked at $80^{\circ} \mathrm{C}$ and steamed for 50 minutes gave the highest yield and best quality rice with a mean value of $93.60 \%, 97.93 \%$, and $91.67 \%$, respectively. According to Musa et al. [23], head rice yield is the current standard to assess commercial rice milling quality, and hydrothermal treatment increases head rice yield which then increases the quality indexes of processed rice [24].

The mean value of broken grains decreased as the soaking temperature and steaming time increased for all the three rice varieties. For instance, at $80^{\circ} \mathrm{C}$ and $50 \mathrm{~min}$ treatment, the percentage of broken rice was $6.4 \%$ (68.53\% for control), $2.07 \%$ (70.47\% for control), and $8.33 \%$ (90.3\% for control) for Gumara, Edget, and Narica4 rice varieties, respectively. Different researchers also reported the good effect of parboiling
TABLE 2: Overall effects of varieties on physical properties.

\begin{tabular}{lccccc}
\hline Variety & $\begin{array}{c}\text { Husking } \\
\text { quality \% }\end{array}$ & $\begin{array}{c}\text { Moisture } \\
\text { content }\end{array}$ & $\begin{array}{c}\% \text { head } \\
\text { rice }\end{array}$ & $\begin{array}{c}\% \\
\text { broken }\end{array}$ & $\begin{array}{c}\% \\
\text { chalkiness }\end{array}$ \\
\hline Edget & $78.62^{\text {ba }}$ & $14.38^{0}$ & $60.40^{!}$ & $39.60^{\beta}$ & $55.18^{\mathrm{b}}$ \\
Gumara & $78.28^{\mathrm{b}}$ & $14.01^{1}$ & $34.41^{ \pm}$ & $65.59^{\alpha}$ & $58.41^{\mathrm{b}}$ \\
Narica4 & $80.02^{\mathrm{a}}$ & $13.62^{2}$ & $32.84^{ \pm}$ & $67.16^{\alpha}$ & $76.68^{\mathrm{a}}$ \\
CV & 3.66 & 4.24 & 25.41 & 18.82 & 30.87 \\
$F$ value & 2.65 & 31.63 & 159.84 & 159.84 & 27.34 \\
\hline
\end{tabular}

${ }^{*}$ Means with the same alphabet, number, symbol, and Greek letter as superscript within columns are not significantly different at $5 \%$.

in reducing the percentage of broken rice during milling. For instance, Ayamdoo et al. [22] reported that broken grains significantly decrease from $47 \%$ of control samples to $9.5 \%$ of parboiled rice. Prasad et al. [21] also reported that percentage of broken rice was significantly reduced from $27.25 \%$ for control to $6.31 \%$ for parboiled treatment.

The mean percentage value of chalkiness for Gumara rice variety ranged from 0 to $97.33 \%$; for Edget, it ranged from 0 to $97.80 \%$ and Narica 4 from 0.13 to $100 \%$ as compared to almost $100 \%$ for the control of all rice varieties. There was a significant difference $(P<0.05)$ with respect to chalkiness in all rice varieties within the treatment combinations. Less mean percentage chalkiness value for Gumara rice variety $(1.53 \%-0.0 \%)$ between $70^{\circ} \mathrm{C}, 10^{\prime}$ and $80^{\circ} \mathrm{C}, 50^{\prime}$; Edget variety (0.87\%-0.0\%) between $60^{\circ} \mathrm{C}, 50^{\prime}$ and $80^{\circ} \mathrm{C}, 50^{\prime}$; and Narica 4 rice variety $(0.93 \%-0.13 \%)$ between $70^{\circ} \mathrm{C}, 50^{\prime}$ and $80^{\circ} \mathrm{C}, 50^{\prime}$ was recorded. Generally, the result this study shows that as the soaking temperature and steaming time increased, the percentage chalkiness decreased. As a result, the endosperm translucency, which is an acceptable quality parameter for rice, was enhanced. The translucency character of the endoderm increases during parboiling treatment, mainly due to the pregelatinization of its starch [25]. This character of the endosperm mostly determines the appearance of the grain, and this is inversely related to the amount of chalkiness. Parboiling and cooking processes disappear partially or totally the chalkiness of rice, which may have no direct effect on cooking and eating qualities. But a large amount of chalkiness downgrades the physical quality, reduces milling recovery, and can determine attractiveness on a competitive price on the market [15, 26-28].

As indicated in Table 2, Edget rice had the highest percentage head rice $(60.4 \%)$ compared to the other two rice varieties. Similarly, less percentage of broken rice $(39.6 \%)$ and chalkiness $(55.18 \%)$ was recorded for Edget rice. The result of varietal effect indicated that there was no significant difference between Gumara (34.41) and Narica4 (32.84) $(P>0.05)$ rice varieties in terms of head rice yield and percentage of broken rice.

As indicated in Table 3, soaking temperature significantly affected $(P<0.05)$ the percentage of head rice, broken rice, and percentage chalkiness of the rice. As soaking temperature increased, percentage of head rice increased and percentage of broken rice reduced. Chalkiness at $40^{\circ} \mathrm{C}, 50^{\circ} \mathrm{C}$, and $60^{\circ} \mathrm{C}$ was not significantly different from the control $(P>0.05)$ but significant differences were observed at higher 
TABLE 3: Effect of soaking and steaming time on the physical properties of rice varieties (Gumara, Edget, and Narica4).

\begin{tabular}{|c|c|c|c|c|c|}
\hline & & Moisture content & $\%$ head rice & $\%$ broken & $\%$ chalkiness \\
\hline \multirow{8}{*}{ Soaking $\mathrm{T}^{\circ}\left({ }^{\circ} \mathrm{C}\right)$} & 40 & $13.91^{\mathrm{b}}$ & $13.84^{4}$ & $86.16 !$ & $97.62^{\alpha}$ \\
\hline & 50 & $14.38^{\mathrm{a}}$ & $24.50^{3}$ & $75.50^{ \pm}$ & $96.60^{\alpha}$ \\
\hline & 60 & $14.11^{\mathrm{ba}}$ & $35.28^{2}$ & $64.72^{\#}$ & $88.59^{\alpha}$ \\
\hline & 70 & $13.96^{\mathrm{b}}$ & $57.41^{1}$ & $42.59^{\$}$ & $26.82^{\beta}$ \\
\hline & 80 & $13.84^{\mathrm{b}}$ & $85.49^{0}$ & $14.51^{\bigotimes}$ & $0.16^{\gamma}$ \\
\hline & Control & $13.14^{\mathrm{c}}$ & $23.62^{3}$ & $76.38^{ \pm}$ & $100^{\alpha}$ \\
\hline & $\mathrm{CV}$ & 4.24 & 25.41 & 18.82 & 30.87 \\
\hline & $F$ value & 5.79 & 314.20 & 314.20 & 241.63 \\
\hline \multirow{8}{*}{ Steaming time $(\mathrm{min})$} & 10 & $14.25^{\mathrm{a}}$ & $28.05^{3}$ & $71.95^{!}$ & $65.16^{\beta}$ \\
\hline & 20 & $14.06^{\mathrm{a}}$ & $35.45^{2}$ & $64.55^{ \pm}$ & $64.66^{\beta}$ \\
\hline & 30 & $14.02^{\mathrm{a}}$ & $45.10^{1}$ & $54.90^{\#}$ & $64.37^{\beta}$ \\
\hline & 40 & $13.69^{\mathrm{b}}$ & $49.83^{1}$ & $50.17^{\#}$ & $64.22^{\beta}$ \\
\hline & 50 & $14.18^{\mathrm{a}}$ & $58.09^{0}$ & $41.91^{\$}$ & $51.38^{\gamma}$ \\
\hline & Control & $13.14^{\mathrm{c}}$ & $23.62^{3}$ & $76.38^{!}$ & $100^{\alpha}$ \\
\hline & $\mathrm{CV}$ & 4.24 & 25.41 & 18.82 & 30.87 \\
\hline & $F$ value & 5.87 & 53.76 & 53.76 & 4.12 \\
\hline
\end{tabular}

${ }^{*}$ Means with the same alphabet, number, symbol, and Greek letter as superscript within columns are not significantly different at $5 \%$ significance level.

temperatures $\left(70^{\circ} \mathrm{C}\right.$ and $\left.80^{\circ} \mathrm{C}\right)$. Similarly, as steaming time increased, percentage of head rice increased and percentage of broken rice reduced. In addition, steaming time significantly affected $(P<0.05)$ the percentage chalkiness of rice.

3.2. Cooking Properties of Rice Varieties. The minimum cooking time for Gumara ranged from $16 \mathrm{~min}$ (at $40^{\circ} \mathrm{C}, 10^{\prime}$ ) to $23 \mathrm{~min}$ (at $80^{\circ} \mathrm{C}, 50^{\prime}$ ), for Edget $16 \mathrm{~min}$ (at $40^{\circ} \mathrm{C}, 10^{\prime}$ ) to $23 \mathrm{~min}$ (at $80^{\circ} \mathrm{C}, 50^{\prime}$ ), and for Narica4 $15 \mathrm{~min}$ (at $40^{\circ} \mathrm{C}, 10^{\prime}$ ) to $20 \mathrm{~min}$ (at $80^{\circ} \mathrm{C}, 50^{\prime}$ ) (Table 4 ). The trend revealed that when soaking temperature and steaming time increased, the cooking time also increased. The results obtained were similar with that reported by Farhan et al. [20] (20.67 min for nonparboiled rice to 25.00 for parboiled rice), Tetens et al. [29] (15.42-17.20 min for raw and for parboiled rice 20.70$23.05 \mathrm{~min}$ ), Otegbayo et al. [30] (56 min for parboiled and $49 \mathrm{~min}$ for nonparboiled rice), and Kar et al. [31] (22 min for parboiled and $15 \mathrm{~min}$ for raw rice). Cooking time of parboiled rice was longer than the nonparboiled rice because of the strong cohesion between endosperm cells that makes the tightly packed starch granules to hydrate at a slower rate, which leads to a decreased in-water penetration into the grain [30].

As shown in Table 4, the result of water uptake ratio for Gumara rice variety shows that there was no significant difference among each soaking temperature and steaming time treatment combination $(P>0.05)$ from $\left(40^{\circ} \mathrm{C}, 20^{\prime}\right)$ to $\left(80^{\circ} \mathrm{C}\right.$, $\left.50^{\prime}\right)$. But the mean value of water uptake ratio within the treatment combination is ranged from 3.33 at $\left(40^{\circ} \mathrm{C}, 20^{\prime}\right)$ to 3.47 at $\left(80^{\circ} \mathrm{C}, 50^{\prime}\right)$ with the control value of 3.23 . There was no significant difference throughout the treatment combination, including the control for Edget variety $(P>0.05)$. The mean value within the treatment combination is ranged from 3.12 at $\left(40^{\circ} \mathrm{C}, 10^{\prime}\right)$ to 3.40 at $\left(80^{\circ} \mathrm{C}, 50^{\prime}\right)$ with the control value of 3.11 . There was a significant difference between the treat- ment combinations of Narica 4 rice variety $(P<0.05)$. The mean value within the treatment combination is ranged from 3.45 at $\left(80^{\circ} \mathrm{C}, 30^{\prime}\right)$ to 5.08 at $\left(50^{\circ} \mathrm{C}, 50^{\prime}\right)$ with the control value of 4.45. Among those three varieties, Narica4 rice variety achieved the highest mean value of the water uptake ratio. In this study, for Narica4 rice variety, no clear trend was observed with the changes in the water uptake ratio at different storage of treatment combination; however, the results clearly showed that parboiling drastically increased the water uptake ratio of the rice. Hence, for Gumara and Edget varieties, increasing the soaking temperature and soaking time increases the mean value of water uptake ratio. Similar to the result obtained by Otegbayo et al. [30], the water absorption of the parboiled rice was higher $(13.56 \mathrm{ml} / \mathrm{g})$ than that of the nonparboiled rice $(10.31 \mathrm{ml} / \mathrm{g})$. Kurien et al. [31] reported that water absorption capacity, as reflected by the swelling ratio, is significantly low for parboiled rice as compared with raw rice cooked for the same period (at $10 \mathrm{~min}$, raw (2.22) to parboiled (2.06)). However, the samples of raw and parboiled rice cooked to an equivalent degree of softness show that parboiled rice can absorb more water without losing its shape (from 2.06 at $10 \mathrm{~min}$ to 3.55 at $40 \mathrm{~min}$ ) [32]. Mustapha [33] indicates that parboiled rice has higher water absorption, which may be a result of the steaming pressure during parboiling, which in turn, affects starch gelatinization.

The mean value of swelling ratio for Gumara rice variety was ranged from 2.46 at $40^{\circ} \mathrm{C}, 10^{\prime}$ to 3.00 at $80^{\circ} \mathrm{C}, 50^{\prime}$ with the control mean value of 2.77 (Table 4 ). The data revealed that there was a significant difference $(P<0.05)$ within the treatment combination, including the control. The trend of this data for specific Gumara rice variety indicates that the swelling ratio had increased as the soaking and steaming time were increasing. Also, the mean value of Edget rice variety was ranged from 1.11 to 3.15 , and that indicates there was a significant difference $(P<0.05)$. There was no clear trend 
TABLE 4: Cooking property of rice varieties at different soaking temperature and steaming time.

\begin{tabular}{|c|c|c|c|c|c|c|c|c|c|c|}
\hline \multirow[b]{2}{*}{$\begin{array}{l}\text { Soaking } \\
\mathrm{T}\left({ }^{\circ} \mathrm{c}\right)\end{array}$} & \multirow[b]{2}{*}{$\begin{array}{l}\text { Steaming } \\
\text { time (min) }\end{array}$} & \multicolumn{3}{|c|}{ Gumara } & \multicolumn{3}{|c|}{ Edget } & \multicolumn{3}{|c|}{ Narica4 } \\
\hline & & $\begin{array}{l}\text { Minimum } \\
\text { cooking time }\end{array}$ & $\begin{array}{c}\text { Water } \\
\text { uptake } \\
\text { ratio }\end{array}$ & $\begin{array}{l}\text { Swelling } \\
\text { ratio }\end{array}$ & $\begin{array}{l}\text { Minimum } \\
\text { cooking time }\end{array}$ & $\begin{array}{c}\text { Water } \\
\text { uptake } \\
\text { ratio }\end{array}$ & $\begin{array}{l}\text { Swelling } \\
\text { ratio }\end{array}$ & $\begin{array}{l}\text { Minimum } \\
\text { cooking time }\end{array}$ & $\begin{array}{c}\text { Water } \\
\text { uptake } \\
\text { ratio }\end{array}$ & $\begin{array}{l}\text { Swelling } \\
\text { ratio }\end{array}$ \\
\hline 40 & 10 & 16 & $3.27^{\mathrm{bc}}$ & $2.46^{\theta}$ & 16 & $3.12^{\mathrm{a}}$ & $2.11^{\eta \theta}$ & 15 & $3.70^{\text {igh }}$ & $4.59^{\varepsilon}$ \\
\hline 40 & 20 & 16 & $3.33^{\mathrm{bac}}$ & $2.46^{\theta}$ & 16 & $3.25^{\mathrm{a}}$ & $1.88^{l}$ & 15 & $4.31^{\mathrm{edf}}$ & $3.02^{l}$ \\
\hline 40 & 30 & 16 & $3.34^{\mathrm{bac}}$ & $2.47^{\eta \theta}$ & 16 & $3.23^{\mathrm{a}}$ & $2.29^{\eta}$ & 16 & $3.61^{\mathrm{ih}}$ & $3.22^{\iota \theta}$ \\
\hline 40 & 40 & 17 & $3.34^{\mathrm{bac}}$ & $2.53^{\eta \zeta \theta}$ & 16 & $3.15^{\mathrm{a}}$ & $2.33^{\eta \zeta}$ & 16 & $3.67^{\text {igh }}$ & $5.08^{\beta \alpha \gamma}$ \\
\hline 40 & 50 & 17 & $3.35^{\mathrm{bac}}$ & $2.55^{\eta \zeta \theta}$ & 18 & $3.15^{\mathrm{a}}$ & $2.10^{\eta \theta}$ & 16 & $3.93^{\mathrm{ghf}}$ & $5.22^{\alpha}$ \\
\hline 50 & 10 & 17 & $3.26^{\mathrm{bac}}$ & $2.57^{\eta \zeta \theta}$ & 18 & $3.18^{\mathrm{a}}$ & $2.20^{\eta}$ & 16 & $3.98^{\text {eghf }}$ & $3.25^{\iota \theta}$ \\
\hline 50 & 20 & 17 & $3.33^{\mathrm{bac}}$ & $2.58^{\eta \varepsilon \zeta \theta}$ & 18 & $3.16^{\mathrm{a}}$ & $2.14^{\eta}$ & 17 & $4.77^{\mathrm{bac}}$ & $4.88^{\varepsilon \beta \delta \alpha \gamma}$ \\
\hline 50 & 30 & 17 & $3.35^{\mathrm{bac}}$ & $2.58^{\eta \varepsilon \zeta \theta}$ & 18 & $3.18^{\mathrm{a}}$ & $1.11^{\lambda}$ & 17 & $4.08^{\mathrm{egdf}}$ & $5.16^{\beta \alpha \gamma}$ \\
\hline 50 & 40 & 17 & $3.36^{\mathrm{bac}}$ & $2.59^{\eta \varepsilon \zeta \theta}$ & 18 & $3.18^{\mathrm{a}}$ & $1.50^{\kappa}$ & 17 & $4.75^{\mathrm{bac}}$ & $4.09^{\zeta}$ \\
\hline 50 & 50 & 18 & $3.37^{\text {bac }}$ & $2.60^{\eta \varepsilon \zeta \theta}$ & 18 & $3.21^{\mathrm{a}}$ & $1.73^{t}$ & 17 & $5.08^{\mathrm{a}}$ & $4.76^{\varepsilon \beta \delta \gamma}$ \\
\hline 60 & 10 & 19 & $3.36^{\mathrm{bac}}$ & $2.61^{\eta \varepsilon \zeta \theta}$ & 19 & $3.20^{\mathrm{a}}$ & $1.82^{l}$ & 17 & $4.96^{\mathrm{a}}$ & $4.58^{\varepsilon}$ \\
\hline 60 & 20 & 19 & $3.38^{\mathrm{bac}}$ & $2.58^{\eta \varepsilon \zeta \theta}$ & 19 & $3.21^{\mathrm{a}}$ & $2.65^{\varepsilon \delta}$ & 17 & $4.07^{\mathrm{egdf}}$ & $5.17^{\alpha \gamma}$ \\
\hline 60 & 30 & 20 & $3.38^{\mathrm{bac}}$ & $2.60^{\eta \varepsilon \zeta \theta}$ & 19 & $3.15^{\mathrm{a}}$ & $2.76^{\varepsilon \delta \gamma}$ & 17 & $5.03^{\mathrm{a}}$ & $4.92^{\varepsilon \beta \delta \alpha \gamma}$ \\
\hline 60 & 40 & 20 & $3.39^{\mathrm{bac}}$ & $2.60^{\eta \varepsilon \zeta \theta}$ & 19 & $3.24^{\mathrm{a}}$ & $2.60^{\varepsilon}$ & 17 & $3.68^{\mathrm{igh}}$ & $2.94^{l}$ \\
\hline 60 & 50 & 20 & $3.38^{\mathrm{bac}}$ & $2.61^{\eta \varepsilon \zeta \theta}$ & 19 & $3.23^{\mathrm{a}}$ & $2.86^{\beta \delta \gamma}$ & 17 & $4.78^{\mathrm{bac}}$ & $4.88^{\varepsilon \beta \delta \alpha \gamma}$ \\
\hline 70 & 10 & 20 & $3.42^{\mathrm{bac}}$ & $2.63^{\varepsilon \zeta \delta}$ & 21 & $3.36^{\mathrm{a}}$ & $3.04^{\beta \alpha}$ & 18 & $3.97^{\mathrm{eghf}}$ & $3.47^{\eta \theta}$ \\
\hline 70 & 20 & 20 & $3.42^{\mathrm{bac}}$ & $2.62^{\eta \varepsilon \zeta \delta}$ & 21 & $3.30^{\mathrm{a}}$ & $3.15^{\alpha}$ & 18 & $4.82^{\mathrm{ba}}$ & $3.83^{\eta \zeta}$ \\
\hline 70 & 30 & 20 & $3.42^{\mathrm{bac}}$ & $2.64^{\varepsilon \zeta \delta}$ & 22 & $3.33^{\mathrm{a}}$ & $2.90^{\beta \gamma}$ & 19 & $4.41^{\mathrm{dc}}$ & $3.36^{\iota \theta}$ \\
\hline 70 & 40 & 21 & $3.43^{\mathrm{ba}}$ & $2.64^{\varepsilon \zeta \delta}$ & 22 & $3.35^{\mathrm{a}}$ & $2.53^{\varepsilon \zeta}$ & 19 & $4.35^{\mathrm{ed}}$ & $3.14^{\iota \theta}$ \\
\hline 70 & 50 & 21 & $3.44^{\mathrm{ba}}$ & $2.67^{\gamma \varepsilon \zeta \delta}$ & 22 & $3.35^{\mathrm{a}}$ & $1.41^{\kappa}$ & 19 & $3.95^{\mathrm{eghf}}$ & $4.62^{\varepsilon \delta}$ \\
\hline 80 & 10 & 21 & $3.45^{\mathrm{a}}$ & $2.67^{\gamma \varepsilon \zeta \delta}$ & 22 & $3.36^{\mathrm{a}}$ & $2.75^{\varepsilon \delta \gamma}$ & 19 & $4.35^{\mathrm{ed}}$ & $4.61^{\varepsilon}$ \\
\hline 80 & 20 & 22 & $3.46^{\mathrm{a}}$ & $2.73^{\gamma \varepsilon \beta \delta}$ & 23 & $3.33^{\mathrm{a}}$ & $2.31^{\eta \zeta}$ & 20 & $3.64^{\text {ih }}$ & $4.08^{\zeta}$ \\
\hline 80 & 30 & 22 & $3.46^{\mathrm{a}}$ & $2.81^{\gamma \beta}$ & 23 & $3.37^{\mathrm{a}}$ & $2.66^{\varepsilon \delta}$ & 20 & $3.45^{\mathrm{i}}$ & $4.13^{\zeta}$ \\
\hline 80 & 40 & 22 & $3.46^{\mathrm{a}}$ & $2.86^{\beta}$ & 23 & $3.38^{\mathrm{a}}$ & $3.07^{\beta \alpha}$ & 20 & $3.57^{\text {ih }}$ & $5.06^{\beta \delta \alpha \gamma}$ \\
\hline 80 & 50 & 23 & $3.47^{\mathrm{a}}$ & $3.00^{\alpha}$ & 23 & $3.40^{\mathrm{a}}$ & $2.98^{\beta \alpha \gamma}$ & 20 & $3.70^{\text {igh }}$ & $4.63^{\varepsilon \delta}$ \\
\hline Control & & 16 & $3.23^{c}$ & $2.77^{\gamma \beta \delta}$ & 16 & $3.11^{\mathrm{a}}$ & $2.09^{\eta \theta}$ & 15 & $4.45^{\mathrm{bdc}}$ & $4.71^{\varepsilon \delta \gamma}$ \\
\hline & $\mathrm{CV}$ & - & 3.07 & 3.15 & - & 7.53 & 5.71 & - & 5.13 & 5.46 \\
\hline & $F$ value & & 1.24 & 6.45 & & 0.42 & 50.21 & & 16.30 & 31.73 \\
\hline
\end{tabular}

${ }^{*}$ Means with the same alphabet and Greek letter as superscript within columns are not significantly different at 5\%.

observed for the swelling ratio data of Edget variety. Narica4 rice variety has mean value ranged from 2.94 at $60^{\circ} \mathrm{C}, 40^{\prime}$ to 5.22 at $40^{\circ} \mathrm{C}, 50^{\prime}$ with the control mean value of 4.71 . In this study, for Narica4 rice variety, no clear trend was observed with the changes in the swelling ratio at different storage of treatment combination; however, the results clearly showed that parboiling drastically increases the swelling power of the parboiled rice. Kurien et al. [32] reported that the swelling ratio is significantly low for parboiled rice as compared with raw rice cooked for the same period (at $10 \mathrm{~min}$, raw (2.57) to parboiled (2.32)). However, the samples of raw and parboiled rice cooked to an equivalent degree of softness show that parboiled rice can absorb more water without losing its shape (from 2.32 at $10 \mathrm{~min}$ to 4.54 at $40 \mathrm{~min}$ ) [32].

There was a significant difference $(P<0.05)$ in minimum cooking time, water uptake ratio, and swelling ratio among the three varieties (Table 5). The minimum cooking time was recorded for Gumara (19:00 min), whereas the highest water uptake and swelling ratio were recorded for Narica4
TABLE 5: Overall effects of varieties on cooking properties of rice varieties.

\begin{tabular}{lccc}
\hline Variety & $\begin{array}{c}\text { Minimum cooking time } \\
(\mathrm{min})\end{array}$ & $\begin{array}{c}\text { Water uptake } \\
\text { ratio }\end{array}$ & $\begin{array}{c}\text { Swelling } \\
\text { ratio }\end{array}$ \\
\hline Edget & $19.42^{\mathrm{a}}$ & $3.25^{2}$ & $2.35^{\#}$ \\
Gumara & $19.00^{\mathrm{b}}$ & $3.38^{1}$ & $2.63^{ \pm}$ \\
Narica4 & $17.46^{\mathrm{c}}$ & $4.20^{0}$ & $4.28^{!}$ \\
CV & 3.26 & 8.96 & 17.25 \\
$F$ value & 74.93 & 199.19 & 301.48 \\
\hline
\end{tabular}

${ }^{*}$ Means with the same alphabet, number, and symbol as superscript within columns are not significantly different at $5 \%$.

variety which were 4.20 and 4.28 , respectively (Table 5). As indicated in Table 6, some soaking temperatures had significantly affected $(P<0.05)$ the water uptake ratio and swelling ratio of the tested rice. But all steaming times, including the control, did not significantly affected $(P>0.05)$ the water uptake ratio and swelling ratio. 
TABLE 6: Effect of soaking temperature and steaming time on cooking properties for Gumara, Edget, and Narica4 rice varieties.

\begin{tabular}{lccc}
\hline & & Water uptake ratio & Swelling ratio \\
\hline & 40 & $3.45^{\mathrm{b}}$ & $2.95^{1}$ \\
& 50 & $3.68^{\mathrm{a}}$ & $2.92^{1}$ \\
Soaking $\mathrm{T}^{\circ}\left({ }^{\circ} \mathrm{C}\right)$ & 60 & $3.71^{\mathrm{a}}$ & $3.21^{10}$ \\
& 70 & $3.69^{\mathrm{a}}$ & $2.98^{1}$ \\
& 80 & $3.52^{\mathrm{ba}}$ & $3.36^{0}$ \\
& Control & $3.59^{\mathrm{ba}}$ & $3.19^{10}$ \\
& $\mathrm{CV}$ & 8.96 & 17.25 \\
& $F$ value & 5.82 & 5.84 \\
\hline & 10 & $3.59^{\mathrm{a}}$ & $3.02^{0}$ \\
Steaming time (min) & $3.65^{\mathrm{a}}$ & $3.07^{0}$ \\
& 30 & $3.59^{\mathrm{a}}$ & $3.04^{0}$ \\
& 40 & $3.57^{\mathrm{a}}$ & $3.04^{0}$ \\
& Control & $3.65^{\mathrm{a}}$ & $3.24^{0}$ \\
& $\mathrm{CV}$ & $8.59^{\mathrm{a}}$ & $3.19^{0}$ \\
& $F$ value & 0.71 & 17.25 \\
\hline
\end{tabular}

${ }^{*}$ Means with the same alphabet as superscript and number within columns are not significantly different at 5\% significance level.

\section{Conclusion and Recommendation}

The study explored the effect of parboiling on physical and cooking qualities of three rice varieties, Gumara, Edget, and Narica4. Higher soaking temperatures and steaming times increased the head rice yield, water uptake ratio, and swelling ratio and decreased chalkiness and broken rice which are indicators of good quality rice. On the other hand, the swelling ratio for Edget rice and water uptake ratio and swelling ratio for Narica4 variety had no clear trend at treatment conditions. Higher treatment conditions increased the cooking time of parboiled rice varieties compared to the cooking time of nonparboiled rice. In general, parboiling with prolonged soaking temperature and steaming time improved the physical and cooking quality of local rice varieties.

\section{Data Availability}

The husking quality (\%), moisture content (\%), head rice yield (\%), broken rice (\%), chalkiness (\%), minimum cooking time (min), water uptake ratio, and swelling ratio data used to support the findings of this study are included within the article.

\section{Conflicts of Interest}

The authors declare that they have no competing interests.

\section{Authors' Contributions}

MA and DA conceived and designed the experiments. MA, DA, YS, TG, and TK collected and analyzed the data. MA, DA, and SY contributed to the writing of the manuscript.

\section{Acknowledgments}

The authors would like to extend our gratitude to Amhara Agricultural Research Institute (ARARI) for the financial support and Fogera National Rice Research and Training Center for supplying raw materials and allowing to us to use rice dehusking and polishing machine.

\section{References}

[1] M. S. Hossain, A. K. Singh, and Fasih-uz-Zaman, "Cooking and eating characteristics of some newly identified inter subspecific (indica/japonica) rice hybrids," Science Asia, vol. 35, no. 4, pp. 320-325, 2009.

[2] F. M. Anjum, I. Pasha, M. A. Bugti, and M. S. Butt, "Mineral composition of different rice varieties and their milling fractions," Pakistan Journal of Agricultural Science, vol. 44, pp. 332-336, 2007.

[3] A. O. Oko and S. I. Ugwu, "The proximate and mineral compositions of five major rice varieties in Abakaliki, SouthEastern Nigeria," International Journal of Plant Physiology and Biochemistry, vol. 3, pp. 25-27, 2011.

[4] Central statistical agency, Report on Area and Production of Major Crops, Agricultural sample survey, Ethiopia, 2013.

[5] Central statistical agency, Report on Area and Production of Major Crops, Agricultural sample survey, Ethiopia, 2018.

[6] H. Dutta and C. L. Mahanta, "Effect of hydrothermal treatment varying in time and pressure on the properties of parboiled rices with different amylose content," Food Research International, vol. 49, no. 2, pp. 655-663, 2012.

[7] T. A. Shittu, M. B. Olaniyi, A. A. Oyekanmi, and K. A. Okeleye, "Physical and water absorption characteristics of some improved rice varieties," Food Bioprocess Technology, vol. 5, no. 1, pp. 298-309, 2012.

[8] S. D. Deshpande, S. Bal, and T. P. Ojha, "A study on diffusion of water by the soybean grain during cold water soaking," Journal of Food Engineering, vol. 23, no. 1, pp. 121-127, 1994.

[9] J. Patindol, J. Newton, and Y. J. Wang, "Functional properties as affected by laboratory scale parboiling of rough rice and brown rice," Journal of Food Science, vol. 73, pp. 370-377, 2008.

[10] T. Izawa, "The process of rice domestication: a new model based on recent data," Rice, vol. 1, no. 2, pp. 127-134, 2008.

[11] N. Singh, L. Kaur, N. S. Sodhi, and K. S. Sekhon, "Physicochemical, cooking and textural properties of milled rice from different Indian rice cultivars," Food Chemistry, vol. 89, no. 2, pp. 253-259, 2005.

[12] A. I. Chukwuemeka, A. J. Kelechi, and A. Bernard, "Cooking and physicochemical properties of five rice varieties produced in Ohaukwu local government area," European journal of food science and technology, vol. 3, pp. 1-10, 2015.

[13] N. Danbaba, I. Nkama, M. H. Badau et al., "Optimization of rice parboiling process for optimum head rice yield: a response surface methodology (RSM) approach," International Journal of Agriculture and Forestry, vol. 4, pp. 154-165, 2014.

[14] IRRI, "Measuring quality, physical properties of paddy," in TropRice, International Rice Research Institute, pp. 168-169, The Philippines, Los Banos, Laguna, 2002.

[15] E. Adu-Kwarten, W. O. Ellis, I. Oduro, and J. T. Manful, "Rice grain quality: a comparison of local varieties with new varieties 
under study in Ghana," Food Control, vol. 14, no. 7, pp. 507514, 2003.

[16] M. Fofana, J. Wanvoeke, J. Manful et al., "Effect of improved parboiling methods on the physical and cooked grain characteristics of rice varieties in Benin," International Food Research Journal, vol. 18, pp. 715-721, 2011.

[17] WARDA, West Africa Rice Development Association, Grain quality laboratory database, WARDA, Bouake, Mali, 1995.

[18] K. Sareepuang, S. Siriamornpun, L. Wiset, and N. Meeso, "Effect of soaking temperature on physical, chemical and cooking properties of parboiled fragrant rice," World Journal of Agricultural science, vol. 4, pp. 409-415, 2008.

[19] T. M. R. Bleoussi, F. Mamadou, I. Bokossa, and F. Koichi, Effect of parboiling and storage on grain physical and cooking characteristics of the some NERICA rice varieties. Second Africa Rice Congress, Innovation and Partnerships to Realize Africa's Rice Potential, Bamako, Mali, 2009.

[20] F. Saeed, I. Pasha, F. M. Anjum, H. A. R. Suleria, and M. Farooq, "Effect of parboiling on physico-chemical \& cooking attributes of different rice cultivars," Internet journal of food safety, vol. 13, pp. 237-245, 2011.

[21] P. Chavan, S. R. Sharma, T. C. Mittal, G. Mahajan, and S. K. Gupta, "Effect of parboiling technique on physico-chemical and nutritional characteristics of basmati rice," Agricultural Research Journal, vol. 55, no. 3, pp. 490-499, 2018.

[22] A. J. Ayamdoo, B. Demuyakor, W. Dogbe, R. Owusu, and M. A. Ofosu, "Effect of varying parboiling conditions on physical qualities of Jasmine 85 and Nerica 14 rice varieties," American Journal of Food Technology, vol. 8, no. 1, pp. 31-42, 2013.

[23] M. Khammari, DA-Khammari, M. O.-R. Nia, and M. A.-M. Khani, "Parameters and QTLs for milling quality in rice : a review," International Journal of Scientific Research in Science and Technology, vol. 2, pp. 145-149, 2016.

[24] M. Bello, R. Baeza, and M. P. Tolaba, "Quality characteristics of milled and cooked rice affected by hydrothermal treatment," Journal of Food Engineering, vol. 72, no. 2, pp. 124-133, 2006.

[25] M. Kondo, "Analysis on the effects of air temperature during ripening and grain protein contents on grain chalkiness in rice," Japanese Journal of Crop Science, vol. 75, pp. 234-235, 2006.

[26] J. Gayin, J. T. Manful, and P. N. T. Johnson, "Rheological and sensory properties of rice varieties from improvement programme in Ghana," International Food Research Journal, vol. 16, pp. 167-174, 2009.

[27] S. Y. M. Indudhara and K. R. Bhattacharya, "Breakage of rice during milling IV. Effect of kernel chalkiness," Journal of Food Science and Technology, vol. 19, pp. 125-126, 1982.

[28] G. S. Khush, C. M. Paule, and N. M. De la Cruz, "Rice Grain Quality Evaluation and Improvement," in Proceedings of workshop on chemical aspects of rice grain quality, pp. 21-31, Manila, Philippines, 1979.

[29] S. K. Tetens, L. V. Biswas, K. A. Glits, S. H. Kabir, T. Thilsted, and N. H. Choudhury, "Physico-chemical characteristics as indicators of starch availability from milled rice," Journal of Cereal Science, vol. 26, no. 3, pp. 355-361, 1997.

[30] B. O. Otegbayo, F. Osamuel, and J. B. Fashakin, "Effect of parboiling on physico-chemical qualities of two local rice varieties in Nigeria," Journal of Food Technology in Africa, vol. 6, pp. 130-132, 2001.
[31] N. Kar, R. K. Jain, and P. P. Srivastav, "Parboiling of dehusked rice," Journal of Food Engineering, vol. 39, no. 1, pp. 17-22, 1999.

[32] P. P. Kurien, R. Radhakrishnamurthy, H. S. R. Desikachar, and V. Subrahmanyan, "Effect of parboiling on the swelling quality of rice," Cereal Chemistry, vol. 41, pp. 16-22, 1964.

[33] F. O. Mustapha, The effect of parboiling on some physicochemical properties of some local rice varieties, [B.Sc. thesis], University of Ife, 1979. 